\title{
Mutations and Amplification of Oncogenes in Endometrial Cancer
}

\author{
Dieter Niederacher ${ }^{a}$ Han-Xiang An ${ }^{a, b}$ Yong-Jig Cho ${ }^{a}$ Peer Hantschmann ${ }^{c}$ \\ Hans G. Bendera Matthias W. Beckmann ${ }^{a}$

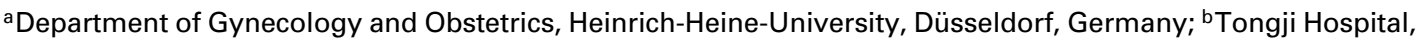 \\ Tongji Medical University, Wuhan, People's Republic of China; 'Department of Gynecology and Obstetrics, \\ Ludwig-Maximilians-University, München, Germany
}

\section{Key Words}

Oncogene $\cdot$ Amplification · Mutation - Endometrial cancer

\begin{abstract}
Alterations in oncogenes are critical steps in the development of endometrial cancer. To investigate the potential clinical relevance of the amplification of the oncogenes $c$-erbB2, $c-m y c$, and int-2 and the mutation of $K$-ras in endometrial cancer, 112 tumors were examined using PCR-based fluorescent DNA technology. Amplification of the three oncogenes and the mutation of $K$-ras were correlated with age, tumor size, lymph node status, metastases, stage, histological types, grade, steroid hormone receptor expression (estrogen receptor, ER; progesterone receptor, PgR), family history of cancer, previous history of cancer or precursor lesions, and previous history of hormone replacement therapy. Oncogene amplification of $c$-erbB2 was detected in $18.9 \%$, of $c$-myc in $2.7 \%$ and of int-2 in $4.2 \%$, and $K$-ras mutation in $11.6 \%$. No significant correlations could be detected between amplification of $c$-erbB2 and any of the other parameters. Mutation of $K$-ras is associated with positive expression of $\mathrm{PgR}$. This might indicate that mutation and activation of $K$-ras are involved in the development of hormonal independence in endometrial cancer.
\end{abstract}

\begin{tabular}{ll}
\hline KARGER & ( 1999 S. Karger AG, Basel \\
Fax +4161306 1234 & 0030-2414/99/0561-0059\$17.50/0 \\
$\begin{array}{l}\text { E-Mail karger@karger.ch } \\
\text { www.karger.com }\end{array}$ & $\begin{array}{l}\text { Accessible online at: } \\
\text { http://BioMedNet.com/karger }\end{array}$
\end{tabular}

\section{Introduction}

Endometrial cancer is the most abundant female genital cancer with a significant increase in the cause-specific death rate over the last few years, which may reflect the aging population $[1,2]$. According to the FIGO classification (1988), the staging of endometrial cancer is based upon surgical findings. The three major criteria for therapeutic decisions include myometrial invasion, tumor grading, and extrauterine tumor spread [3, 4]. The search for prognostic and/or predictive factors in endometrial cancer include DNA ploidy and S-phase [5, 6], expression of the steroid hormone receptors [7-9], the epidermal growth factor receptor, the Her-2/neu protein, and the p53 protein [10-15]. In these studies tumors with high FIGO classification showed decreased estrogen (ER) and progesterone receptor $(\mathrm{PgR})$ expression [7, 8] and increased epidermal growth factor receptor, Her-2/neu, and p53 expression [6, 11-15]. By univariant or multivariant analyses, none of these parameters proved to be more relevant than the three major prognostic parameters. Genetic alterations in the development of endometrial carcinomas have not been well characterized, little is known about oncogene and tumor suppressor gene activity in these carcinomas. Cytogenetic and molecular genetic analyses of endometrial cancer samples have found amplification of the $c$-erbB2 gene $[10,11]$, mutations in the

Dieter Niederacher, $\mathrm{PhD}$

Frauenklinik and Molekularbiologisches Labor

Heinrich-Heine-Universität, Moorenstrasse 5

D-40225 Düsseldorf (Germany)

Tel./Fax +49211811 5319, E-Mail niederac@uni-duesseldorf.de 
$p 53$ gene $[14,15]$, microsatellite instability and mutation in the K-ras gene [16-19], deletion in the $D C C$ gene [20], and loss of heterozygosity at chromosomes $1 \mathrm{p}, 3 \mathrm{p}, 8 \mathrm{p}, 9 \mathrm{p}$, $10 \mathrm{q}, 14 \mathrm{q}, 16 \mathrm{q}, 17 \mathrm{q}$, and $18 \mathrm{q}$ [21-24]. The main focus of these studies was directed towards their relevance for tumor development and their role in the multistep carcinogenesis of endometrial cancer. They encompass a small number of cases and do not focus on prognostic values or correlations with histological or clinical parameters.

Gene amplification is a common mechanism of protooncogene activation and is believed to play a key role in neoplastic cell transformation and tumor progression. Mutations in oncogenes are a rare phenomenon. In this retrospective study, a rapid, non-radioactive, highly sensitive approach based on differential PCR and fluorescent DNA technology for quantitative determination of oncogene amplification in formalin-fixed, paraffin-embedded endometrial carcinomas was established. Furthermore, a fluorescence-based sequencing strategy was used for confirmation of single-strand conformation polymorphism (SSCP) screened alterations in the $K$-ras oncogene.

\section{Materials and Methods}

Patient Characteristics, Surgical Procedures, and Adjuvant Thera$p y$. The study included 112 patients who were treated for primary endometrial cancer at the Department of Obstetrics and Gynecology, Heinrich-Heine-University, Düsseldorf, from January 1980 to December 1994 and from whom complete follow-up data were available. An abdominal hysterectomy and bilateral oophorectomy were performed in all patients. In 75 patients with advanced stage or palpable lymph nodes, lymphadenectomy was performed by removing the lymphatic tissue along the external and internal iliac veins and arteries, and in the obturator fossae. Para-aortic lymphadenectomy was only performed in case of positive palpation. Patients with deep myometrial invasion ( $>50 \%$ ) or undifferentiated tumors (G3) were treated with postoperative brachytherapy to the vaginal vault. Eight patients received external beam irradiation, 11 patients adjuvant hormonal therapy (TAM, MPA), none chemotherapy. Staging was performed according to the FIGO classification of 1988. Anamnestic information included age, family history of gynecological or breast cancer (at least 1 case), previous history of cancer or preceding lesions, and history of hormonal therapy (oral contraceptives, hormone replacement therapy). Patients were followed clinically for up to 186 months (median 98 months). Recurrences were histologically confirmed. Death reports were available.

Histology and DNA Extraction. Formalin-fixed, paraffin-embedded blocks of tumor specimens and additional non-tumor tissue from 112 patients were analyzed. 93\% of the tumors encompassed endometrioid adenocarcinomas of various types (papillary, secretory, ciliated cell, adenoacanthoma, adenosquamous), 7\% were clear cell, serous or mucinous carcinoma. In addition, 5 different myometrium samples randomly chosen from each year $(1980-1994$; total $n=90)$ served as controls to test the influence of fixatives, or fixation time on
DNA quality. For tumor samples, hematoxylin-eosin staining was used for a repeated pathologic evaluation (e.g. TNM status, myometrial invasion, grading, histological typing, lymph node involvement). ER and PgR expression was determined and scored on newly prepared 5- $\mu \mathrm{m}$ sections by immunohistochemistry [25]. The amount of tumor cells in sections of endometrial carcinomas was estimated by visual examination of $5-\mu \mathrm{m}$ HE-stained sections. Adjacent $40-\mu \mathrm{m}$ toluidine-stained tumor sections with a high content of tumor cells $(>70 \%)$ were used for microdissection [26]. DNA was extracted from the tumor sections as previously described [27].

Amplification of c-erbB2, c-myc and int-2 Gene. Differential PCR combined with fluorescent DNA technology was used for quantitative determination of $c$-erbB2, $c-m y c$ and int-2 oncogene amplification in tumor samples. PCR reactions, fragment analysis, and assessment of oncogene amplification were performed as previously reported [27, 28]. Briefly, the gene of interest and an unamplified reference gene $(y-I F N)$ were amplified in a multiplex PCR using fluorescent-labelled primers. In each PCR experiment, DNA extracted from normal placenta as reference tissue with non-amplified target genes was included. PCR products were electrophoresed on an automated fluorescent DNA sequencer (A.L.F. ${ }^{\text {TM }}$ Pharmacia, Freiburg, Germany). Fluorescent emission data collected during the electrophoresis were calculated using AlleleLinks ${ }^{\mathrm{TM}}$ software (Pharmacia). Amplification of target genes in tumor tissue, which reflects the ratio of the gene copy numbers of the oncogene and the $y-I F N$ reference gene, was estimated from the ratio of peak areas using placenta DNA for normalization. Results of at least two independent assays were calculated with the equation: amplification $n=\left(\mathrm{P}_{\mathrm{t}} / \mathrm{P}_{\mathrm{r}}\right) /\left(\mathrm{P}_{\mathrm{t} \text { placenta }} / \mathrm{P}_{\mathrm{r} \text { placenta }}\right)$, where $P_{t}=$ peak area of target gene signal and $P_{r}=$ peak area of reference gene signal $(y-I F N)$.

Mutation of the K-ras Gene. Mutation of the K-ras gene at codons $12 / 13$ and 61 were examined by PCR-SSCP and direct sequencing. Exon 1 and 2 of the $K$-ras gene were amplified by PCR using the following primer pairs: for codon 12/13, 5'-CATGTTCTAATATAGTCACA-3' (forward) and 5'-GTTATCTCCATTTAGAACAA$3^{\prime}$ (reverse); for codon 61, 5'-TTCCTACAGGAAGCAAGTAG-3' (forward) and 5'-GATGAACGAAGGACATCCTT-3' (reverse). PCR was performed in $50 \mu \mathrm{l}$ with $2 \mu \mathrm{l}$ of genomic DNA isolated from paraffin sections, 40 pmol of each primer, $20 \mathrm{mM}$ Tris- $\mathrm{HCl}$ (pH 8.4), $50 \mathrm{mM} \mathrm{KCl}, 1.5 \mathrm{mM} \mathrm{MgCl} 2,200 \mu M$ of each dNTP and 2.0 units of Taq polymerase (Pharmacia). An initial denaturation of $10 \mathrm{~min}$ at $94^{\circ} \mathrm{C}$ was followed by 35 cycles of $1 \mathrm{~min}$ at $94^{\circ} \mathrm{C}, 1 \mathrm{~min}$ at $49^{\circ} \mathrm{C}$ for codon $12 / 13$ or at $55^{\circ} \mathrm{C}$ for codon 61 and $1 \mathrm{~min}$ at $72^{\circ} \mathrm{C}$, and a final elongation step $\left(8 \mathrm{~min}\right.$ at $\left.72^{\circ} \mathrm{C}\right)$. PCR products were screened for mutations by the SSCP method on $6 \%$ polyacrylamide gels run at $5 \mathrm{~W}$ at $10^{\circ} \mathrm{C}$ and visualized by silver staining as described [29]. For sequencing, PCR products were purified with the MicroSpin Columns (Pharmacia). Both strands of DNA were sequenced by the dideoxy method using Thermo-Sequenase according to the manufacturer's protocol (Amersham Life Science, Slough, UK).

Statistical Methods. Associations of $c$-erbB2 amplification and $K$ ras mutation with other clinicopathological factors were calculated by $\chi^{2}$ test. Probabilities of relapse-free survival and overall survival (OS) were calculated using the method of Kaplan-Meier, statistical differences were evaluated by log-rank test. 
Fig. 1. Analysis of $c$-erbB2 amplification by fluorescent differential PCR. Electrophoretogram of PCR products of $c$-erbB2 gene ( 98 bp) and the control locus $y$-IFN ( $85 \mathrm{bp})$ in representative cases. The data were obtained with an automated fluorescent DNA sequencer (ALF, Pharmacia) and analyzed with Fragment Manager ${ }^{\mathrm{TM}}$ software. The abscissa of the electrophoretogram shows the fragment size in base pairs. Lane $1=$ Tumor with low amplification; lane $3=$ tumor with high amplification; lane 27 = placenta with no amplification (normal control).

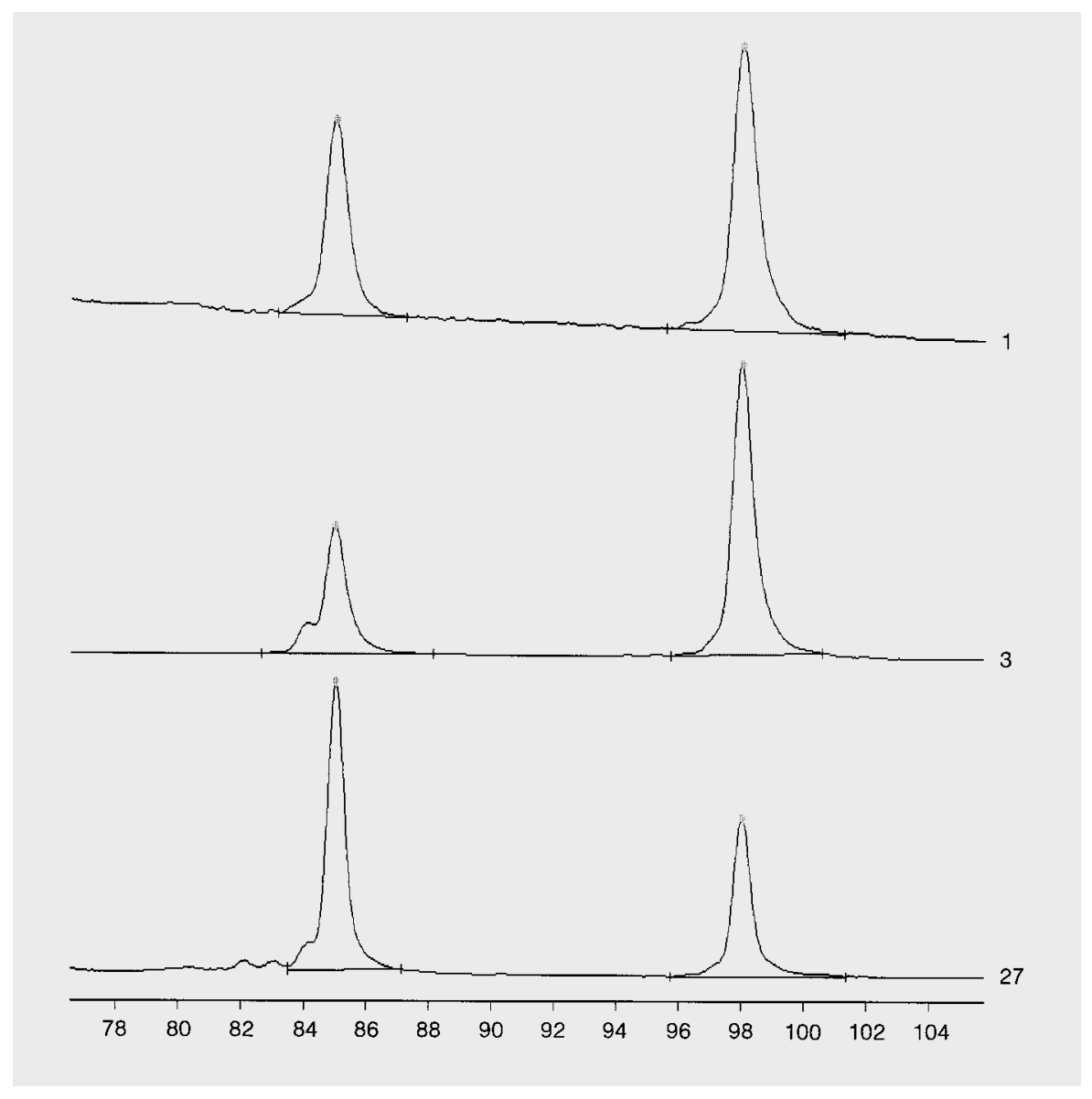

\section{Results}

In DNA extracted from sections of a total of 112 primary endometrial cancers with reference tissue from the same patients and in 90 benign, randomly chosen myometrium samples, amplification of c-erbB2, c-myc and int-2 was analyzed using fluorescent differential PCR (fig. 1). c-erbB2 gene amplification (2- to 10-fold) was observed in 21(18.6\%) of the 112 endometrial carcinomas examined. Amplification of $c-m y c$ and int-2 genes was found in 3 (2.7\%, 3- to 4-fold) and 5 (4.4\%, 2- to 5-fold) tumors, respectively (table 1). No amplification of the three oncogenes could be detected in any of the benign reference and additional myometrium samples analyzed.

All cases were screened for mutations at codon 12/13 and codon 61 of the $K$-ras oncogene by PCR-SSCP analysis and direct double-stranded DNA sequencing. K-ras mutations were observed in $13(11.5 \%)$ of 112 carcinomas, 10 mutations were found in codon 12 , and 3 in codon 61 (table 1, fig. 2).

Oncogene Alterations in Endometrial Cancer
Table 1. Frequencies of $c$-erbB2, $c-m y c$ and int-2 amplification and $K$-ras mutation in 112 endometrial cancers

\begin{tabular}{lrr}
\hline & $\mathrm{n}$ & \multicolumn{1}{c}{$\%$} \\
\hline$c$-erbB2 & 21 & 18.6 \\
$c$-myc & 3 & 2.7 \\
int-2 & 5 & 4.4 \\
K-ras & & \\
$\quad$ codon 10 & 12 & 8.9 \\
\multicolumn{1}{c}{ codon 61 } & 3 & 2.7 \\
\hline
\end{tabular}

Due to the low number of $c-m y c$ and int-2 amplification, no associations between amplification of these genes and clinical factors were analyzed. Associations between $c$ erbB2 gene amplification and $K$-ras mutation and patient age and pathohistological factors were determined (table 2). No significant associations between c-erbB2 gene 

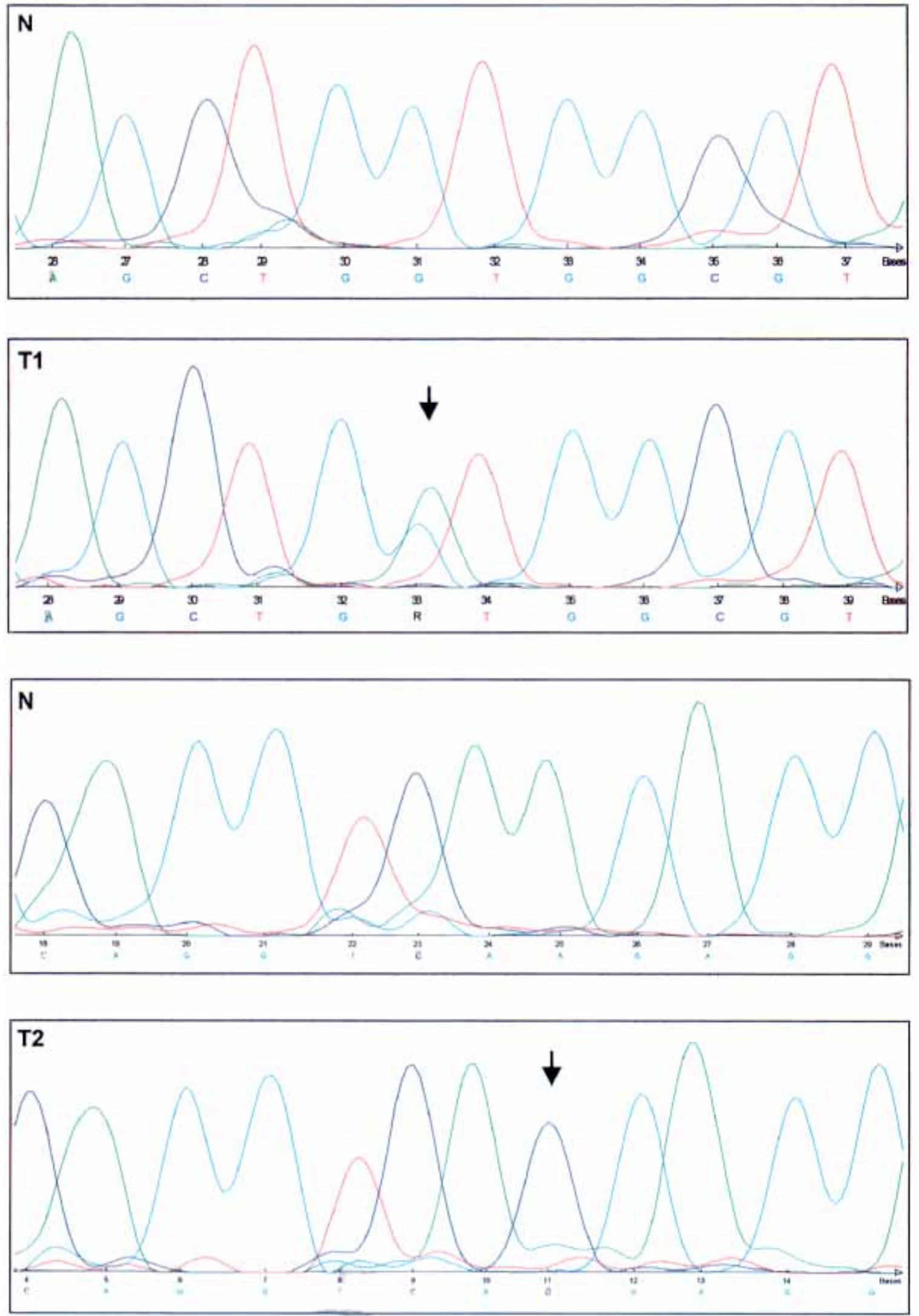
Table 2. Amplification of $c$-erbB2 and mutation of $K$-ras correlated with patients' age and histopathological tumor characteristics of 112 endometrial cancers

\begin{tabular}{|c|c|c|c|}
\hline Criteria & $\begin{array}{l}\text { Patients } \\
(\mathrm{n}=112)\end{array}$ & $\begin{array}{l}c \text {-erbB2 } \\
\text { amplification }\end{array}$ & $\begin{array}{l}K \text {-ras } \\
\text { mutation }\end{array}$ \\
\hline \multicolumn{4}{|l|}{ Age } \\
\hline$<50$ & 8 & & \\
\hline$\geq 50$ & 104 & $\mathrm{p}=0.64$ & $\mathrm{p}=0.65$ \\
\hline \multicolumn{4}{|l|}{ Tumor } \\
\hline $\mathrm{T} 1$ & 70 & & \\
\hline $\mathrm{T} 2$ & 20 & $\mathrm{p}=0.56$ & $\mathrm{p}=0.24$ \\
\hline $\mathrm{T} 3 / 4$ & 22 & & \\
\hline \multicolumn{4}{|l|}{ Nodes } \\
\hline NO & 97 & & \\
\hline $\mathrm{N} 1 / 2$ & 15 & $\mathrm{p}=0.22$ & $\mathrm{p}=0.27$ \\
\hline \multicolumn{4}{|l|}{ Metastases } \\
\hline M0 & 98 & & \\
\hline M1 & 14 & $\mathrm{p}=0.50$ & $\mathrm{p}=0.15$ \\
\hline \multicolumn{4}{|l|}{ Grade } \\
\hline I & 51 & & \\
\hline II & 30 & $\mathrm{p}=0.24$ & $\mathrm{p}=0.39$ \\
\hline III & 21 & & \\
\hline \multicolumn{4}{|l|}{ Stage } \\
\hline I & 69 & & \\
\hline II & 18 & $\mathrm{p}=0.31$ & $\mathrm{p}=0.18$ \\
\hline III & 14 & & \\
\hline IV & 11 & & \\
\hline \multicolumn{4}{|l|}{ Family history } \\
\hline positive & 16 & $\mathrm{p}=0.19$ & $\mathrm{p}=0.21$ \\
\hline negative & 96 & & \\
\hline \multicolumn{4}{|l|}{ HRT } \\
\hline positive & 17 & $\mathrm{p}=0.42$ & $\mathrm{p}=0.37$ \\
\hline negative & 95 & & \\
\hline \multicolumn{4}{|l|}{ ER } \\
\hline negative & 52 & & \\
\hline positive & 50 & $\mathrm{p}=0.89$ & $\mathrm{p}=0.23$ \\
\hline ND & 10 & & \\
\hline \multicolumn{4}{|l|}{$\mathrm{PgR}$} \\
\hline negative & 51 & & \\
\hline positive & 51 & $\mathrm{p}=0.62$ & $\mathrm{p}=0.041$ \\
\hline ND & 10 & & \\
\hline
\end{tabular}

$\mathrm{ND}=$ Not done HRT $=$ hormone replacement therapy.

Fig. 2. Demonstration of $K$-ras mutation by fluorescence-based direct DNA sequencing. $\mathrm{N}=$ Normal control; $\mathrm{T}=$ tumor. The arrowheads indicate the mutations in the sequence. T1 shows a heterozygous point mutation at codon 12 (GGT to GAT, Gly to ASP), T2 shows a homozygous point mutation at codon 61 (CAA to CAC, Gln to His).

Oncogene Alterations in Endometrial

Cancer
Table 3. Age, histopathological findings, staging, steroid hormone receptor expression, amplification of $c$-erbB2 and $K$-ras mutation in 112 sporadic endometrial cancers correlated with DFS and OS

\begin{tabular}{|c|c|c|}
\hline Criteria & DFS & OS \\
\hline \multicolumn{3}{|l|}{ Age } \\
\hline$<50$ vs. $\geq 50$ years & $p=0.16$ & $\mathrm{p}=0.14$ \\
\hline \multicolumn{3}{|l|}{ Tumor } \\
\hline T1 vs. T2 & $\mathrm{p}<0.01$ & $\mathrm{p}<0.01$ \\
\hline T1 vs. T3/4 & $\mathrm{p}<0.01$ & $\mathrm{p}<0.01$ \\
\hline T2 vs. T3/4 & $\mathrm{p}=0.014$ & $\mathrm{p}=0.025$ \\
\hline \multicolumn{3}{|l|}{ Nodes } \\
\hline N0 vs. N1 & $\mathrm{p}=0.14$ & $\mathrm{p}=0.296$ \\
\hline Metastases & $\mathrm{p}=0.048$ & $\mathrm{p}=0.039$ \\
\hline \multicolumn{3}{|l|}{ Grading } \\
\hline G1 vs. G2 & $\mathrm{p}=0.32$ & $\mathrm{p}=0.721$ \\
\hline G1 vs. G3 & $\mathrm{p}<0.01$ & $\mathrm{p}<0.01$ \\
\hline G2 vs. G3 & $\mathrm{p}=0.01$ & $\mathrm{p}=0.015$ \\
\hline Staging & $\mathrm{p}=0.13$ & $\mathrm{p}=0.36$ \\
\hline \multicolumn{3}{|l|}{ Family history } \\
\hline negative vs. positive & $\mathrm{p}=0.48$ & $\mathrm{p}=0.52$ \\
\hline \multicolumn{3}{|l|}{ HRT } \\
\hline negative vs. positive & $\mathrm{p}=0.78$ & $\mathrm{p}=0.63$ \\
\hline \multicolumn{3}{|l|}{ ER } \\
\hline negative vs. positive & $\mathrm{p}=0.64$ & $\mathrm{p}=0.30$ \\
\hline \multicolumn{3}{|l|}{$\mathrm{PgR}$} \\
\hline negative vs. positive & $\mathrm{p}=0.03$ & $\mathrm{p}=0.016$ \\
\hline Amplification of $c$-erbB2 & $\mathrm{p}=0.389$ & $\mathrm{p}=0.222$ \\
\hline Mutation of $K$-ras & $\mathrm{p}=0.339$ & $\mathrm{p}=0.451$ \\
\hline
\end{tabular}

amplification and any clinical factor were observed. K-ras gene mutation correlated significantly with higher $\mathrm{PgR}$ expression $(p<0.05)$, but with none of the other clinical parameters and survival of the patients (table 2). For disease-free survival (DFS) and overall survival (OS) clinical parameters including $\mathrm{PgR}$ expression revealed significant prognostic value. For $c$-erbB2 amplification and $K$-ras mutation no prognostic information was achieved (table 3 ).

\section{Discussion}

The systemic management of endometrial cancer patients is mainly based on histopathological criteria such as myometrial invasion, tumor grading, and extrauterine 
tumor spread. However, these parameters are evidently unable to sufficiently characterize the biological behavior of endometrium cancer $[1,2]$. Analyses of genetic alterations are relevant for the understanding of tumor genetics and may provide prognostic information for the individual patient $[15,30]$. The role of oncogene activation in endometrial cancer is incompletely characterized. Most of the studies published on oncogene amplification in endometrial cancer only examined small numbers of cases, often with conflicting results [10-12, 31-33]. In this study, amplification of $c-e r b B 2, c-m y c$, and int-2 were determined in 112 endometrial cancers. To date, this is the largest study performed on endometrial cancer bearing oncogene amplification with differential PCR. Amplification of $c-e r b B 2, c-m y c$ and int-2 were found in 18.6, 2.7 and $4.4 \%$ of endometrial cancers analyzed. The detected rates of oncogene amplification are in agreement with previous studies [10-12, 31-33].

Amplification of $c-m y c$ or int-2 is very low, implicating a subordinate role of these oncogenes in the development of sporadic endometrial cancer. Numerous studies have demonstrated that amplification and overexpression of $c$ $e r b B 2$ in endometrial cancer correlated with clinical and pathohistological factors such as histological grade. Furthermore, it was suggested that c-erbB2 is of prognostic value $[10-12,31,32]$. In contrast to these findings, we could not demonstrate any significant correlation between the amplification of the $c-e r b B 2$ gene and clinical factors, as well as the DFS and OS of the patients. These results have been supported by Monk et al. [33]. Sample size, tumor histology or technical variations may account for this discrepancy. Further studies in strictly defined populations with standard analytical techniques may have to clarify the prognostic significance of $c$-erbB2 amplification in endometrial cancer.

A rare genetic phenomenon is the mutation of an oncogene. Mutations in the K-ras oncogene occur in 10-50\% of several tumor types including endometrial cancer [1618]. $K$-ras mutations also have been found in endometrial hyperplasia, suggesting that activation of $K$-ras represents an early event in the development of endometrial cancer [16]. In this study, K-ras mutations could be detected in $11.5 \%$ of endometrial cancers. There were no correlations between $K$-ras point mutation and clinical stage, histological grade and clinical outcome of the patients, in agreement with other studies [16-18, 34]. Mutations of the ras oncogene alter the ras product by abolishing their intrinsic GTPase activity, which results in autonomous cell growth [35]. Activation of the guanine nucleotide binding protein ras enhance estrogen-induced and antiestrogen (tamoxifen)-induced transcriptional activity of the ER activation function $1[36,37]$. These findings are in agreement with the results of this study. A significant correlation was found between ER-dependent PgR expression and activating $K$-ras mutations. This suggests that enhanced activity of the ER activation function 1 by stimulating phosphorylation mediated through mutational activation of the ras-MAPK cascade may be one mechanism of hormone independence of endometrial cancer. This may contribute to the development of (anti-)hormone resistance of steroid-receptor-positive endometrial cancer.

\section{Acknowledgments}

This work was supported by a grant ['Sonderforschungsbereich 351: Hormonresistenz: Biochemie und Klinik (DFG/SFB 351-95/ A8)'] from the 'Deutsche Forschungsgemeinschaft', Bonn, Germany, and by the 'Wilhelm Vaillant Stiftung', München, Germany. The authors would like to thank the staff from the operating room and the technicians from the Laboratory of Pathomorphology, Frauenklinik, Heinrich-Heine Universität, Germany, for the recruitment of the tumors, their expert technical assistance and persistent support.

\section{References}

1 Park RC, Grigsby PW, Muss HB, Norris HJ: Corpus: Epithelial tumours; in Hoskins WJ, Perez CA, Young RC (eds): Principles and Practice of Gynecologic Oncology. Philadelphia, Lippincott, 1992, pp 663-694.

2 Homesley HD: Management of endometrial cancer. Am J Obstet Gynecol 1996;174:529534

3 Homesley HD, Zaino R: Endometrial cancer: Prognostic factors. Semin Oncol 1994;21:7178.
4 Lampe B, Kürzl R, Hantschmann P: Prognostic factors that predict pelvic lymph node metastases from endometrial cancer. Cancer 1994; 74:2502-2508.

5 Friberg LG, Noren H, Delle U: Prognostic value of DNA ploidy and S-phase fraction in endometrial cancer stage I and II: A prospective 5-year survival study. Gynecol Oncol 1994;53:64-69.
6 Lukes AS, Kohler MF, Pieper CF, Kerns BJ, Bentley R, Rodriguez GC, Soper JT, ClarkePearson DL, Bast RC Jr, Berchuck A: Multivariable analysis of DNA ploidy, p53, and HER-2/neu as prognostic factors in endometrial cancer. Cancer 1994;73:2380-2385.

7 Ehrlich CE, Young PCM, Stehman FB, Sutton GP, Alford WM: Steroid receptors and clinical outcome in patients with adenocarcinoma of the endometrium. Am J Obstet Gynecol 1988; 158:796-807. 
8 Borazjani G, Twiggs LB, Leung BS, Prem KA, Adcock LL, Carson LF: Prognostic significance of steroid receptors measured in primary metastatic and recurrent endometrial carcinoma. Am J Obstet Gynecol 1989;161:1253-1257.

9 Murphy LJ: Growth factors and steroid hormone action in endometrial cancer. J Steroid Biochem Mol Biol 1994;48:419-423.

10 Hetzel DJ, Wilson TO, Keeney GL, Roche PC, Cha SS, Podratz KC: HER-2/neu expression: A major prognostic factor in endometrial cancer. Gynecol Oncol 1992;47:179-185.

11 Khalifa MA, Mannel RS, Haraway SD, Walker J, Min KW: Expression of EGFR, HER-2/neu, p53, and PCNA in endometrioid, serous papillary, and clear cell endometrial adenocarcinomas. Gynecol Oncol 1994;53:84-92.

12 Saffari B, Jones LA, el-Naggar A, Felix JC, George J, Press MF: Amplification and overexpression of HER-2/neu (c-erbB2) in endometrial cancers: Correlation with overall survival. Cancer Res 1995;55:5693-5698.

13 Berchuck A, Kohler MF, Marks JR, Wiseman $\mathrm{R}$, Boyd J, Bast RC: The p53 tumour suppressor gene frequently is altered in gynecologic cancers. Am J Obstet Gynecol 1994;170:246252.

14 Schneider J, Rubio MP, Rodriguez-Escudero FJ, Seizinger BR, Castresana JS: Identification of p53 mutations by means of single strand conformation polymorphism analysis in gynaecological tumours: Comparison with the results of immunohistochemistry. Eur J Cancer 1994; 30A:504-508.

15 Berchuck A, Boyd J: Molecular basis of endometrial cancer. Cancer 1995;76(suppl 10): 2034-2040.

16 Enomoto T, Inoue M, Perantoni AO, Buzard GS, Miki H, Tanizawa O, Rice JM: K-ras activation in premalignant and malignant epithelial lesions of the human uterus. Cancer Res 1991;51:5308-5314.

17 Caduff RF, Johnston CM, Frank TS: Mutations of the Ki-ras oncogene in carcinoma of the endometrium. Am J Pathol 1995;146:182188.

18 Duggan BD, Felix JC, Muderspach LI, Tsao JL, Shibata DK: Early mutational activation of the c-Ki-ras oncogene in endometrial carcinoma. Cancer Res 1994;54:1604-1607.
19 Duggan BD, Felix JC, Muderspach LI, Tourgeman D, Zheng J, Shibata DK: Microsatellite instability in sporadic endometrial carcinoma. J Natl Cancer Inst 1994;86:1216-1221.

20 Gima T, Kato H, Honda T, Imamura T, Sasazuki T, Wake N: DCC gene alteration in human endometrial carcinomas. Int $\mathrm{J}$ Cancer 1994;57:480-485.

21 Okamoto A, Sameshima Y, Yamada Y, Teshima S, Terashima Y, Terada M, Yokota J: Allelic loss on chromosome $17 \mathrm{p}$ and p53 mutations in human endometrial carcinoma of the uterus. Cancer Res 1991;51:5632-5635.

22 Fujino T, Risinger JI, Collins NK, Liu FS, Nishii H, Takahashi H, Westphal EM, Barrett JC, Sasaki H, Kohler MF: Allelotype of endometrial carcinoma. Cancer Res 1994;54:42944298.

23 Jones MH, Koi S, Fujimoto I, Hasumi K, Kato K, Nakamura Y: Allelotype of uterine cancer by analysis of RFLP and microsatellite polymorphisms: Frequent loss of heterozygosity on chromosome arms 3p, 9q, 10q, and 17p. Genes Chromosom Cancer 1994;9:119-123.

24 Ambros RA, Vigna PA, Figge J, Kallakury BV, Mastrangelo A, Eastman AY, Malfetano J, Figge HL, Ross JS: Observations on tumour and metastatic suppressor gene status in endometrial carcinoma with particular emphasis on p53. Cancer 1994;73:1686-1692.

25 Beckmann MW, Tutschek B, Göhring UJ, Engels K, Picard F, Scharl A, Niederacher D, Schnürch HG: Immunohistochemical detection of epidermal growth factor receptor (EGFR) in paraffin sections of breast carcinoma tissue: Correlation and clinical significance. Geburtshilfe Frauenheilkd 1995;55:258-265.

26 Niederacher D, Picard F, van Roeyen CRC, An HX, Bender HG, Beckmann MW: Patterns of allelic loss on chromosome 17 in sporadic breast cancer detected by fluorescent labelled microsatellite analysis. Genes Chromosome Cancer 1997;8:181-192.

27 An HX, Niederacher D, Beckmann MW, Göhring UJ, Scharl A, Picard F, van Roeyen CRC, Schnürch HG, Bender HG: ERB2 gene amplification detected by fluorescent differential polymerase chain reaction in paraffinembedded breast carcinoma tissues. Int J Cancer 1995;64:291-297.
28 Niederacher D, Schnürch HG, An HX, Ellenberger I, Dall P, van Roeyen CRC, Küppers V, Beckmann MW: Detection of sequential genetic alterations relevant for breast cancer development. Eur J Cancer Prev 1996;5:497-503.

29 Sugano K, Kyogoku A, Fukayama N, Ohkura H, Shimosato Y, Sekiya T, Hayashi K: Methods in laboratory investigation. Rapid and simple detection of c-Ki-ras2 gene codon 12 mutations by nonradioisotopic single-strand conformation polymorphism analysis. Lab Invest 1993;68:361-366.

30 Brison O: Gene amplification and tumor progression. Biochim Biophys Acta 1993;1155: 25-41.

31 Borst MP, Baker VV, Dixon D, Hatch KD, Shingleton HM, Miller DM: Oncogene alterations in endometrial carcinoma. Gynecol Oncol 1990;38:364-366.

32 Esteller M, Garcia A, Martinez I, Palones JM, Cabero A, Reventos J: Detection of c-erbB-2/ neu and fibroblast growth factor-3/INT-2 but not epidermal growth factor receptor gene amplification in endometrial cancer by differential polymerase chain reaction. Cancer 1995; 75:2139-2146.

33 Monk BJ, Chapman JA, Johnson GA, Brightman BK, Wilczynski SP, Schell MJ, Fan H: Correlation of $C-m y c$ and HER-2/neu amplification and expression with histopathologic variables in uterine corpus cancer. Am J Obstet Gynecol 1994;171:1193-1198.

34 Caduff RF, Johnston CM, Frank TS: Mutations of the Ki-ras oncogene in carcinoma of the endometrium. Am J Pathol 1995; 146:182188.

35 Barbacid M: ras gene. Annu Rev Biochem 1987;56:779-827.

36 Kato S, Endoh H, Masuhiro Y, Kitamoto T, Uchiyama S, Sasaki H, Masushige S, Gotoh Y, Nishida E, Kawashima H, Metzger D, Chambon P: Activation of the estrogen receptor through phosphorylation by mitogen-activated protein kinase. Science 1995;270:1491-1494.

37 Bunone G, Briand PA, Miksicek RJ, Picard D: Activation of the unliganded estrogen receptor by EGF involves the MAP kinase pathway and direct phosphorylation. EMBO J 1996;15: 2174-2183. 